\title{
THE INFLUENCE OF CONTEXTUAL TEACHING AND LEARNING APPROACH AND LEARNING MOTIVATION TOWARD WRITING SKILLS OF PANTUN IN THE FIFTH GRADE STUDENTS OF ELEMENTARY SCHOOL
}

\author{
Resti Adna Helda ${ }^{1}$, Mardiah Harun ${ }^{2}$, Syahrul R $^{3}$ \\ 1,2,3 Universitas Negeri Padang, Padang, Indonesia \\ 11resti1921@gmail.com, ${ }^{2}$ Harun_Mardiah@yahoo.co.id, ${ }^{3}$ Syahrul_810@yahoo.co.id
}

\begin{abstract}
This study was conducted to observe the effect of the Contextual teaching and learning (CTL) approach and learning motivation on the skills of writing Pantun of fifth graders in elementary school. This research was an experimental research with the subject of fifth grade students and carried out in Elementary School Cluster I Pariaman City. The research instruments were a learning motivation questionnaire and performance test. Data analysis was carried out using a two-way ANAVA and t-test. Learning outcomes obtained by using the CTL approach to students was higher than conventional methods, both low motivation and high motivation. CTL approach makes students more interested and enthusiastic in learning to write Pantun. As well as creating new experiences for students, it makes students active and learning more fun compared to conventional methods which make some students become passive.
\end{abstract}

Keywords: contextual teaching and learning approach, writing pantun, learning motivation

\section{PENGARUH PENDEKATAN CONTEXTUAL TEACHING AND LEARNING DAN MOTIVASI BELAJAR TERHADAP KETERAMPILAN MENULIS PANTUN SISWA KELAS V SEKOLAH DASAR}

\begin{abstract}
ABSTRAK
Penelitian ini dilakukan untuk mengamati pengaruh pendekatan Contextual teaching and learning (CTL) dan motivasi belajar terhadap keterampilan menulis pantun siswa kelas $V$ sekolah dasar. Penelitian ini merupakan penelitian eksperimen dengan subjek siswa kelas $V$ dan di laksanakan di SD Negeri Gugus I Kota Pariaman. Instrumen penelitian adalah angket motivasi belajar dan tes unjuk kerja .Analisis data dilakukan dengan menggunakan anava 2 jalur daan uji T. Hasil belajar yang diperoleh dengan menggunakan pendekatan CTL pada siswa lebih tinggi dari pada dibandingkan dengan metode konvensional, baik yang memiliki motivasi rendah maupun motivasi tinggi. Pendekatan CTL membuat siswa lebih tertarik dan bersemangat dalam belajar menulis pantun. Serta menciptakan pengalaman baru bagi siswa, membuat siswa aktif, membuat belajar lebih menyenangkan dibandingkan dengan metode konvensional yang membuat beberapa siswa menjadi pasif.
\end{abstract}

Kata Kunci: pendekatan contextual teaching and learning, menulis pantun, motivasi belajar

\begin{tabular}{|c|c|c|}
\hline Submitted & Accepted & Published \\
\hline 03 Mei 2020 & 14 Juli 2020 & 25 Juli 2020 \\
\hline
\end{tabular}

\begin{tabular}{|l|c|c|c|}
\hline Citation & $:$ & $\begin{array}{r}\text { Helda, R.A., Harun, M., \& R. Syahrul. (2020). The Influence of Contextual Teaching and Learning Approach and } \\
\text { Learning Motivation toward Writing Skills of Pantun in the Fifth Garde Students of Elementary School. Jurnal } \\
\text { PAJAR (Pendidikan dan Pengajaran), 4(4), 812-818. DOI : http://dx.doi.org/10.33578/pjr.v4i2.8039. }\end{array}$ \\
\hline
\end{tabular}

\section{PENDAHULUAN}

Menulis merupakan pengetahuan yang paling kompleks, dengan menulis seseorang dapat mengungkapkan gagasan dan pemikirannya kedalam bentuk bahasa. Untuk dapat menulis dengan baik, siswa perlu menerapkan proses menulis dengan tepat, mulai dari kegiatan pra menulis, saat menulis dan pasca menulis serta menerapkan aturan penulisan, dan aturan tata bahasa dengan benar, (Nair, 2018).

Hal itu dapat dilakukan oleh guru dalam melakukan pembelajaran dalam kelas kepada siswa dengan cara memberikan informasi tentang cara 
menulis dengan baik, kemudian memberi umpan balik, dan berlatih dengan giat untuk meningkatkan keterampilan menulis, karena latihan menulis sangat membantu siswa untuk dapat menulis dengan jelas, spesifik, dan konstruktif.

Di sekolah dasar salah satu pembelajaran menulisnya terdapat pada KD 3.4 dan KD 3.6 tentang pantun. Pantun merupakan salah satu karya sastra yang penggunaannya meluas. Meluasnya penggunaan pantun terdapat di media massa, seperti ditelevisi dan internet. Pantun disebut puisi lama atau puisi rakyat karena pantun diciptakan oleh rakyat dan dipakai untuk keperluan rakyat, (Khoirotunisa, 2018).

Ciri-ciri pantun yang benar yaitu tiap bait terdiri empat baris, setiap baris terdiri dari 8-12 suku kata, dua baris pertama merupakan sampiran dan dua baris ke dua merupakan isi, bersajak silang atau a-b-a-b, pantun berisi curahan perasaan, pikiran dan kehendak, dan kenangan, serta pantun yang bermutu yaitu adanya hubungan antara sampiran dan isi, (Muryanto, 2017:13).

Namun kenyataan yang ditemukan di lapangan dalam menulis pantun siswa tidak sesuai dengan ciri-ciri pantun yang benar. Berdasarkan data dari hasil menulis pantun siswa kelas V ditemukan bahwa 4 orang siswa belum menulis pantun sama sekali, 8 orang siswa membuat pantun dalam 2 baris, 1 sampiran dan 1 isi. 7 orang siswa menulis pantun tidak bersajak ab ab, 3 orang siswa tidak membuat pantun dalam 4 baris dan tidak terdiri dari 4 suku kata, 3 orang siswa membuat pantun yang sama.

Sementara permasalahan yang ditemukan berdasarkan data dari angket yang diberikan kepada 8 orang guru kelas $\mathrm{V}$ gugus I Kota Pariaman terlihat, bahwa 37\% guru mengatakan selalu dan $37 \%$ lainya mengatakan sering mengajarkan pantun hanya menggunakan materi yang terdapat pada buku paket, 25\% guru mengatakan jarang dan $37 \%$ lainya mengatakan kadang-kadang menguasai materi membuat pantun, artinya guru kurang menguasai materi menulis pantun, $67 \%$ guru hanya mementingkan hasil menulis pantun dari pada proses menulis pantun siswa, dan $75 \%$ guru mengatakan kadangkadang menggunakan pendekatan pembelajaran dalam menulis pantun, dan 50\% guru jarang merancang penilaian pembelajaran menulis pantun sesuai dengan deskriptor yang tepat.

Permasalahan yang sama juga ditemukan, bahwa penyebab rendahnya keterampilan siswa dalam menulis pantun, karena guru belum mengaitkan materi pantun dengan pengetahuan awal yang dimiliki siswa, sehingga siswa belum maksimal dalam membuat hubungan antara pengetahuan awalnya dengan materi pantun yang akan dipelajari, (Putri, 2017).

Semua permasalahan tersebut dapat terjadi karena selama ini guru hanya menggunakan pendekatan konvensional. Pembelajaran konvensional dilakukan dengan satu arah, (Djaafar, 2001:86). Siswa hanya melakukan dua kegiatan yaitu mendengarkan dan mencatat. Pembelajaran konvensional didominasi oleh guru dengan metode ceramah dan tanya jawab, serta memberikan beberapa contoh soal dan penjelasan. Kemudian siswa yang belum mengerti diberi kesempatan untuk bertanya. Selanjutnya siswa ditugaskan mengerjakan soal-soal latihan.

Melihat permasalahan di atas diperlukan pendekatan pembelajaran untuk meningkatkan keterampilan menulis pantun. Menurut Andarini menyatakan bahwa terdapat perbedaan yang signifikan terhadap hasil pembelajaran yang menggunakan pendekatan CTL dibandingkan dengan pendekatan konvensional, (Andarini, 2012).

Motivasi merupakan faktor penting yang mempengaruhi peningkatan keterampilan menulis pantun. Penelitian yang dilakukan oleh Koca menyatakan motivasi untuk belajar mengacu pada kompetensi yang diperoleh melalui pengalaman umum yang sebagian besar distimulasi melalui pemodelan, komunikasi harapan, dan instruksi langsung atau sosialisasi signifikan yang dilakukan oleh orang lain, (Koca, 2016).

Berkaitan dengan motivasi menulis, penelitian dari Akyol, menemukan bahwa ketika motivasi siswa untuk menulis meningkat, nilai menulis mereka juga meningkat, (Akyol, 2008). Dari penelitian yang dilakukan ditemukan bahwa tingkat motivasi menulis seseorang berkaitan dengan hasil penulisan yang dilakukanya.

Siswa memiliki motivasi belajar yang berbeda-beda. Ada siswa yang motivasi belajarnya 
tinggi dan ada juga siswa yang motivasi belajarnya rendah. Adanya motivasi belajar yang tinggi akan menunjukkan hasil belajar yang baik. Siswa yang motivasi belajarnya tinggi akan giat berusaha, tampak gigih, tidak mau menyerah, serta giat membaca untuk meningkatkan prestasi serta memecahkan masalah yang dihadapi. Sebaliknya, siswa yang motivasi belajarnya rendah akan tampak acuh tak acuh, mudah putus asa, perhatiannya tidak tertuju pada pelajaran akibatnya siswa mengalami kesulitan dalam belajar.

\section{METODE PENELITIAN}

Penelitian ini adalah penelitian Quasi Eksprimental. Dalam penelitian ini, desain yang akan digunakan adalah factorial design $2 \times 2$. Factorial design adalah desain yang memperhatikan kemungkinan adanya moderator yang mempengaruhi perlakuan (variabel
Melihat permasalahan itu, penulis merasa perlu untuk melakukan sebuah penelitian agar terjadi peningkatan dalam proses pembelajaran. Oleh karena itu penulis tertarik melakukan penelitian eksperimen yang berhubungan dengan penggunaan pendekatan CTL dan motivasi belajar terhadap kemampuan menulis pantun. Maka tujuan penelitian ini adalah untuk mengetahui pengaruh pendekatan CTL dan motivasi belajar terhadap keterampilan siswa menulis pantun di kelas V gugus I Kota Pariaman.

independen) terhadap hasil (variabel dependen), (Sugiyono, 2012:113) Eksperimen tersebut direncanakan oleh penulis untuk mengumpulkan data yang diperlukan dalam pengujian hipotesis penelitian ini.

Tabel 1. Desain Penelitian

\begin{tabular}{lcc}
\hline $\begin{array}{c}\text { Pendekatan pembelajaran } \\
\text { Motivasi belajar }\end{array}$ & Pendekatan CTL (B1) & $\begin{array}{c}\text { Pendekatan Konvensional } \\
\text { (B2) }\end{array}$ \\
\hline Tinggi (A1) & $\mathrm{A}_{1} \mathrm{~B}_{1}$ & $\mathrm{~A}_{1} \mathrm{~B}_{2}$ \\
\hline Rendah (A2) & $\mathrm{A}_{2} \mathrm{~B}_{1}$ & $\mathrm{~A}_{2} \mathrm{~B}_{2}$ \\
\hline
\end{tabular}

Populasi pada penelitian ini adalah seluruh siswa SD Negeri kelas V Gugus I yang terdaftar pada tahun ajaran 2019/2020. Teknik sampling yang digunakan pada penelitian ini adalah cluster random sampling. Jadi sampel diambil secara acak dengan menentukan terlebih dahulu bahwa variansi dari populasi homogen, sehingga sampel pada penelitian ini dibagi menjadi dua kelas, yaitu kelas eksperimen di SDN 21 Jalan Kereta Api, sedangkan kelas kontrol di SDN 02 Karan Aur.

Sebelum angket diberikan kepada siswa maka dibuat terlebih dahulu butir pertanyaan angket menggunakan kisi-kisi yang dikemukakan oleh Hamzah (2009: 23) setelah itu, dilakukan uji coba angket untuk mendapatkan data yang valid, instrumen penelitian yang digunakan harus memenuhi persyaratan tertentu. Persyaratan yang diperlukan antara lain adalah uji validitas, reliabilitas angket motivasi. Cara yang digunakan dalam pengujian validitas anadalah dengan rumus korelasi Pearson Product Moment. Berikut ini merupakan rumus Pearson Product Moment yang peneliti gunakan (Idris, 2010: 8).

$$
r_{X Y}=\frac{n\left(\sum X Y\right)-\left(\sum X \cdot \sum Y\right)}{\sqrt{\left[n \sum X^{2}-\left(\left(\sum X\right)^{2}\right]\left[n \sum Y^{2}-\left(\sum Y\right)^{2}\right]\right.}}
$$

Setelah diperoleh rhitung, kemudian dibandingkan dengan rtabel dengan taraf signifikan 5\%. Jika rhitung > rtabel, maka butir soal tersebut dikatakan valid. Untuk menentukan reliabilitas tes angket motivasi digunakan rumus Cronbach Alpha dengan ketentuan apabila nilai crombach Alpha lebih besar dari 0,6 maka menunjukkan variabel tersebut reliable. Maka digunakan rumus sebagai berikut.

$$
r_{11}=\left(\frac{k}{k-1}\right)\left(1-\frac{\sum \sigma b^{2}}{\sigma_{t}^{2}}\right)
$$


Langkah selanjutnya yang akan dilakukan adalah menginterpretasikan besarnya koefisien korelasi. Hal ini berguna untuk mengetahui tingkat reliabilitas tes.

Selanjutnya tes unjuk kerja digunakan untuk mengukur keterampilan menulis pantun siswa. Langkah-langkah yang akan dilakukan dalam menyusun instrumen tes adalah membuat kisi-kisi penilaian berdasarkan indikator menulis pantun. Penilaian dilakukan dengan mengubah skor menulis pantun berdasarkan PAP (penilaian acuan patokan) untuk menghitung nilai yang diperoleh siswa dilakukan berdasarkan rumus persentase sebagai berikut:

$$
N=\frac{S M}{S I} x S \max
$$

(Abdurahman, 2003:264)

Untuk mengubah nilai digunakan persentase. Setelah mendapatkan nilai hasil penguasaan menulis pantun siswa, dilakukan uji normalitas, uji homogenitas dan uji hipotesis. Sebelum dilakukan pengujian hipotesis, terlebih dahulu dilakukan uji persyaratan hipotesis penelitian yang dilakukan dengan menggunakan uji normalitas dan uji homogenitas.

Uji normalitas bertujuan untuk melihat apakah data berdistribusi normal atau tidak. Uji normalitas memakai uji Lilliefors Uji normalitas memakai uji Lilliefors, (Sudjana, 2005:466-467). Hasil dari uji normalitas diambil harga yang paling besar diantara harga mutlak selisih tersebut yang disebut $\mathrm{L}_{0}$. Kemudian Membandingkan nilai $\mathrm{L}_{0}$ dengan nilai kritis $\mathrm{L}_{\text {tabel}}$, untuk mengetahui data berdistribusi normal atau tidak.

\section{HASIL DAN PEMBAHASAN}

Data yang diperoleh dari penelitian ini berasal dari angket motivasi belajar yang dikelompokan menjadi motivasi rendah dan
Uji homogenitas bertujuan untuk melihat apakah data memiliki varians yang homogen atau tidak. Untuk menguji homogenitas data dilakukan uji F. Kemudian diacari variansi dari seluruh data dengan mencari harga F. Setelah itu bandingkan harga Fhitung tersebut dengan harga Ftabel yang terdapat pada daftar distribusi $F$ dengan taraf signifikan yang dipilih, dengan $\mathrm{dk}$ pembilang $=\mathrm{n}_{1}$ -1 , dk penyebut $=\mathrm{n}_{2}-1$. Bila harga Fhitung itu lebih kecil dari Ftabel bearti data memiliki varians yang homogen. Bila harga $F_{\text {hitung }}$ itu lebih besar dari $\mathrm{F}_{\text {tabel }}$ bearti data memiliki varians yang tidak homogen.

Adapun pertanyaan khusu yang harus dijawab pada penelitian ini adalah :

1. Apakah keterampilan menulis pantun siswa yang diajar dengan Pendekatan CTL lebih tinggi daripada keterampilan menulis pantun siswa yang diajar dengan pendekatan konvensional?

2. Apakah keterampilan menulis pantun siswa yang memiliki motivasi belajar tinggi yang diajar dengan Pendekatan CTL lebih tinggi daripada keterampilan menulis pantun siswa yang memiliki motivasi belajar tinggi yang diajar dengan pendekatan konvensional ?

3. Apakah keterampilan menulis pantun siswa yang memiliki motivasi belajar rendah yang diajar dengan pendekatan konvensional lebih tinggi daripada keterampilan menulis pantun siswa yang memiliki motivasi belajar rendah yang diajar dengan Pendekatan CTL.

4. Apakah terdapat interaksi yang signifikan antara Pendekatan CTL dengan motivasi siswa terhadap keterampilan menulis pantun?

motivasi tinggi. Data hasil dari angket motivasi dapat dilihat pada tabel di bawah. 
Tabel 2. Deskripsi Data Hasil Angket Motivasi Belajar Menulis Pantun

\begin{tabular}{ccc}
\hline & Kelas Eksperimen & Kelas Kontrol \\
\hline $\mathrm{N}$ & 25 & 25 \\
Mean & 91.71 & 90.18 \\
Standar Deviasi & 11.944 & 10.249 \\
Varians & 142.65 & 105.04 \\
Nilai Minimum & 71 & 65 \\
Nilai Maksimum & 112 & 105 \\
\hline
\end{tabular}

Data di atas diambil sebelum pembelajaran menulis pantun dilaksanakan. Data tersebut menjelaskan bahwa rata-rata motivasi siswa kelas eksperimen lebih tinggi dari kelas kontrol. Motivasi belajar kelas eksperimen lebih bervariasi dari kelompok kotrol. Data hasil belajar pada penelitian diperoleh melalui tes unjuk kerja masing-masing kelas eksperimen dan eksperimen kontrol. Setelah diberikan tes unjuk kerja maka didapat hasil rerata yang disajikan pada tabulasi berikut

Tabel 3.Perbandingan Rerata Hasil Tes Unjuk Kerja Menulis Pantun Siswa

\begin{tabular}{ccccc}
\hline Kelas Perlakuan & Motivasi Belajar & Skor rerata & SD & N \\
\hline Pendekatan CTL & Rendah & 79.26 & 7.87 & 13 \\
& Tinggi & 88.02 & 4.42 & 12 \\
& Total & 83.82 & 7.62 & 25 \\
Konvensional & Rendah & 68.28 & 8.27 & 13 \\
& Tinggi & 79.11 & 5.62 & 12 \\
& Total & 73.91 & 8.81 & 25 \\
\hline
\end{tabular}

Setelah dilakukan perhitungan diperoleh hasil tes unjuk kerja siswa siswa kelas eksperimen dan kelas control. Pengaruh penggunaan pendekatan CTL dan motivasi belajar. Hasil tes unjuk kerja yang diberikan kepada kelas eksperimen dan kelas control baik yang memiliki motivasi tinggi dan motivasi rendah didapat bahwa rerata kelas eksperimen lebih tinggi dibandingkan kelas kontrol . rerata kelas kontrol adalah 73.91, sedangkan rerata kelas eksperimen adalah 83.82.

Sedangkan rerata hasil tes unjuk kerja pada kelas kontrol dengan motivasi tinggi adalah 79.11 dan rerata hasil tes unjuk kerja pada kelas eksperimen dengan motivasi tinggi adalah 88.02. Rerata hasil tes unjuk kerja pada kelas kontrol dengan motivasi rendah adalah 68.28 dan rerata hasil tes unjuk kerja pada kelas eksperimen dengan motivasi rendah adalah 79.26.

Berdasarkan hasil analisis data menulis pantun siswa kelas V SD Negeri 21 Jalan Kereta Api Kota Pariaman yang diteliti, menunjukkan bahwa siswa yang diajar dengan Pendekatan CTL baik secara keseluruhan, baik kelompok siswa yang memiliki motivasi belajar yang tinggi maupun kelompok siswa yang memiliki motivasi belajar yang rendah. Secara emperis ini terbukti dari hasil uji hipotesis. Pengujian hipotesis bertujuan untuk melihat dari perlakuan yang diterapkan sampel penelitian. Hipotesis ini dilakukan setelah mengetahui hasil tes keterampilan menulis pantun. Hipotesis 1, 2, dan 3 menggunakan rumus uji t, sedangkan hipotesis 4 menggunakan rumus uji $\mathrm{F}$.

Berdasarkan penghitungan hipotesis 1 yang telah dilakukan, hasil pengujian hipotesis 1 menggunakan uji $\mathrm{t}$ diperoleh varians gabungan kedua sampel adalah 9.377 untuk taraf nyata $\alpha=$ $0.05 \mathrm{dk} 48$, sehingga $t_{\text {hitung }}$ yang dihasilkan adalah 2.879. Sedangkan $t_{\text {tabel }}$ yang diperoleh adalah 2.010. Karena $t_{\text {hitung }}$ lebih besar daripada $t_{\text {tabel }}$, maka H0 ditolak dan H1 diterima. Hal ini berarti bahwa keterampilan menulis pantun siswa yang diajar 
dengan Pendekatan CTL lebih tinggi daripada keterampilan menulis pantun siswa yang diajar dengan pendekatan konvensional.

Berdasarkan perhitungan hipotesis 2 yang telah dilakukan dengan menggunakan uji $t$ diperoleh varians gabungan kedua sampel adalah 4.725 untuk taraf nyata $\alpha=0.05 \mathrm{dk} 24$, sehingga $\mathrm{t}_{\text {hitung }}$ yang dihasilkan adalah 2.432. Sedangkan $\mathrm{t}_{\text {tabel }}$ yang diperoleh adalah 2.063. Karena thitung lebih besar daripada $t_{\text {tabel}}$, maka $\mathrm{H} 0$ ditolak dan $\mathrm{H} 1$ diterima. Hal ini berarti bahwa keterampilan menulis pantun siswa yang memiliki motivasi belajar tinggi yang diajar dengan Pendekatan CTL lebih tinggi daripada keterampilan menulis pantun siswa yang memiliki motivasi belajar tinggi yang diajar dengan pendekatan konvensional.

Berdasarkan penghitungan hipotesis 3 yang telah dilakukan dengan menggunakan uji $\mathrm{t}$ diperoleh varians gabungan kedua sampel adalah 8.076 untuk taraf nyata $\alpha=0.05 \mathrm{dk} 22$, sehingga $\mathrm{t}_{\text {hitung }}$ yang dihasilkan adalah 2.531. Sedangkan $\mathrm{t}_{\text {tabel }}$ yang diperoleh adalah 2.063. Karena thitung lebih besar daripada $t_{\text {tabel}}$, maka $\mathrm{H}_{0}$ ditolak dan $\mathrm{H}_{1}$ diterima. Hal ini berarti bahwa keterampilan menulis pantun siswa yang memiliki motivasi belajar rendah yang diajar dengan pendekatan konvensional lebih tinggi daripada keterampilan menulis pantun siswa yang memiliki motivasi belajar rendah yang diajar dengan Pendekatan CTL.

Berdasarkan penghitungan hipotesis 4 yang telah dilakukan dengan menggunakan uji $\mathrm{F}$ diperoleh $F_{\text {hitung }}$ sebesar 0.299. Sedangkan $F_{\text {tabel }}$ yang diperoleh adalah 4.022. Karena $F_{\text {hitung }}$ lebih kecil daripada $\mathrm{F}_{\text {tabel}}$, maka $\mathrm{H}_{0}$ diterima dan $\mathrm{H}_{1}$ ditolak. Hal ini berarti bahwa tidak terdapat interaksi yang signifikan antara Pendekatan CTL dengan motivasi siswa terhadap keterampilan menulis pantun.

\section{SIMPULAN DAN REKOMENDASI}

Berdasarkan hasil penelitian disimpulkan pertama, keterampilan menulis pantun siswa yang diajar dengan pendekatan CTL lebih tinggi daripada keterampilan menulis pantun siswa yang diajar dengan pendekatan konvensional. Kedua, keterampilan menulis pantun siswa yang memiliki
Dari semua paparan dan hasil penelitian jelas bahwa pendekatan memberikan pengaruh terhadap pembelajaran menulis pantun siswa. Hal ini sesuai dengan pendapat Hosnan, yang menyatakan bahwa pendekatan CTL memberikan kesempatan kepada siswa untuk membangun sendiri pengetahuannya dan mengaitkan materi dengan kehidupan nyata sehingga pada materi menulis pantun siswa dapat dengan mudah menulis kalimat pada pantun dengan baik, (Hosnan, 2014 : 282). Pendapat tersebut sejalan dengan. Jadi, keunggulan CTL dibandingkan pendekatan konvensional adalah bahwa CTL membelajarkan siswa untuk memahami konsep, CTL membelajarkan siswa untuk aktif dan berpikir kritis, dan CTL membelajarkan siswa untuk belajar mandiri dan kerja sama dalam tim. CTL berfokus pada keaktifan siswa dalam kegiatan pembelajaran dalam suasana yang dikaitkan dalam kehidupan yang nyata sehingga dapat memberikan pengalamn belajar yang menyenangkan bagi siswa. Siswa tidak lagi diberikan materi belajar secara satu arah seperti pada pembelajaran konvensional dan dengan menggunakan Pendekatan CTL maka siswa mengembangkan pengetahuannya secara mandiri.

Siswa yang diberi tugas secara kelompok maka hasil yang diperoleh diakui sebagai hasil dari pekerjaan bersama, (Uno, 2007:31). Dari keadaan yang ada saat penelitian, hal ini mendorong siswa yang memiliki motivasi rendah untuk berusaha keras menyelesaikan tugasnya. Siswa yang memiliki motivasi rendah yang awalnya tidak memperdulikan tugas kelompok menjadi lebih termotivasi lagi karena adanya ancaman akan dikucilkan temannya apabila tidak ikut andil dalam penyelesaian tugas.

motivasi belajar tinggi yang diajar dengan pendekatan CTL lebih tinggi daripada keterampilan menulis pantun siswa yang memiliki motivasi belajar rendah yang diajar dengan pendekatan konvensional. Ketiga, keterampilan menulis pantun siswa yang memiliki motivasi 
belajar rendah yang diajar dengan pendekatan konvensional lebih tinggi daripada keterampilan menulis pantun siswa yang memiliki motivasi belajar rendah yang diajar dengan pendekatan CTL. Keempat, tidak terdapat interaksi yang signifikan antara pendekatan CTL dengan motivasi

\section{DAFTAR PUSTAKA}

Akyol, H., \& Aktas, N. (2018). The Relationship between Fourth-Grade Primary School Students' Story-Writing Skills and Their Motivation to Write. Universal Journal of Educational Research, 6(12), 2772-2779.

Andarini, T. (2012). Pembelajaran biologi menggunakan pendekatan CTL (contextual teaching and learning) melalui media flipchart dan video ditinjau dari kemampuan verbal dan gaya belajar. Doctoral dissertation. UNS (Sebelas Maret University).

Djaafar, Z. (2001). Kontribusi Strategi Pembelajaran terhadap Hasil Belajar. Fakultas Ilmu Pendidikan: Universitas Negeri Padang.

Hamzah, B.U. (2011). Teori. Motivasi dan Pengukurannya Analisis di Bidang Pendidikan. Jakarta: Bumi Aksara.

Hosnan, M. (2014). Pendekatan Saintifik dan Kontekstual dalam Pembelajaran Abad 21: Kunci Sukses Implementasi Kurikulum 2013. Bogor: Ghalia Indonesia.

Idris. (2010). Aplikasi Model Analisis Data Kuantitatif Dengan Program SPSS Edisi Revisi III. Fakultas Ekonomi: Universitas Negeri Padang.

Khoirotunnisa, R. P., Hasanah, M., \& Dermawan, T. (2018). Pengembangan Bahan Ajar Menulis Pantun Bermuatan Nilai Budaya dengan Strategi Pohon Kata untuk Siswa Kelas VII. Jurnal Pendidikan: Teori, Penelitian, dan Pengembangan, 3(2), 238244.

Koca, F. (2016). Motivation to Learn and TeacherStudent Relationship. Journal of International Education and Leadership, 6(2), 2161-7252. siswa terhadap keterampilan menulis pantun. Penelitian ini menyarankan agar guru SD dapat menggunakan pendekatan CTL untuk meningkatkan kemampuan menulis pantun siswa sekolah dasar.

Muryanto, A. K. (2017). Mengenal Pantun. Surabaya: PT Temprina Media Grafika.

Nair, S. M., \& Sanai, M. (2018). Effects of Utilizing the STAD Method (Cooperative Learning Approach) in Enhancing Students' Descriptive Writing Skills. International Journal of Education and Practice, 6(4), 239-252.

Putri, N. K. (2017). Penerapan Metode Drill dalam Pembelajaran Bahasa Indonesia Materi Pantun Anak Pada Siswa Kelas IV. A MIN Bireuen Tahun Pelajaran 2016/2017. Jurnal Media Inovasi Edukasi (JMIE), 3(3), 34-39.

Sudjana, N. (2009). Penilaian hasil belajar mengajar. Bandung: Remaja Rosdakarya

Sugiyono. (2012). Metode Penelitian Pendidikan Kualitatif, Kuantitatif, dan $R \& D$. Bandung: Alfabeta.

Uno, H. (2007). Teori Motivasi \& Pengukurannya. Jakarta: Bumi Aksara. 